\title{
PENGARUH PENAMBAHAN TAMENG PALU TERHADAP PENGURANGAN RISIKO KECELAKAAN PEKERJA PENAMBANGAN EMAS DI DESA PANINGKABAN KECAMATAN GUMELAR KABUPATEN BANYUMAS TAHUN 2016
}

\author{
Mimma Nur Fatiha ${ }^{1)}$, Dr. Djamaluddin Ramlan ${ }^{2)}$ \\ Jurusan Kesehatan Lingkungan, Politeknik Kesehatan Kemenkes Semarang, \\ Jl.Raya Baturaden KM 12 Purwokerto, Indonesia
}

\begin{abstract}
Abstrak
Pekerja fisik yang bekerja di lingkungan tidak formal seperti pekerja pemecah batu memiliki potensi yang besar untuk memperoleh celaka, hal ini disebabkan karena aktivitas dilakukan dengan peralatan seadanya, tanpa dilengkapi dengan alat pelindung diri dengan tuntutan produksi maksimal. Tujuan dari penelitian ini adalah menemukan palu yang dapat mengatasi resiko celaka serta memberi rasa aman dan nyaman bagi pekerja untuk beraktifitas. Metode penelitian yang digunakan adalah pre eksperimen. Penelitian dilakukan pada 14 pekerja pengolahan emas dibawah koordinasi Bapak Bambang Priyono di Desa paningkaban Kecamatan Gumelar Kabupaten Banyumas. Pengumpulan data dilakukan dengan wawancara, pengamatan, pengukuran dan perhitungan. Hasil dari penelitian dengan uji statistik Wilcoxon diperoleh nilai $\mathrm{Th}>\mathrm{Tt}(23>21)$ yang artinya ada pengaruh penambahan tameng palu terhadap pengurangan risiko kecelakaan kerja. Simpulan dari penelitian ini adalah ada pengaruh penambahan tameng palu terhadap penurunan risiko kecelakaan kerja. Sebaiknya pekerja pemecah batu menggunakan palu yang diberi tameng.
\end{abstract}

Kata kunci: Tameng Palu

\begin{abstract}
The Influence Of Adding Hammer Shield In Decreasing The Risk Of The Crash Workers Gold Mining In Paningkaban Village Gumelar Subdistrict Banyumas County In The Year Of 2016. Physical workers who work in informal environtment like stone-breaker worker have a great risk to get accident. This is because the activities they have done still using conventional tools without having self-protection tools yet the work itslef demands high production. The purpose of this research is to find out a hammer which can overcame the risk of the crash work as well as giving feel of safety and comfortable to the workers for their work activities. The research methodology of this research is pre-experimental. The research was done to the 14 processing gold workers. In collecting the data, the researcher used interview, observation, measurement and calculation. The result of this research whic used Wilcoxon statistic test showed that the score of Th $>$ Tt $(23>21)$. It means that there is an influence of adding hamer in decreasing the risk of the crash work. The conclusion of this research is there is an influence of adding hammer shield in decreasing the risk of the crash work. So, it would be better if the stone-breaker worker use hammer which is given a shield.
\end{abstract}

Keywords: Hammer Shield

\footnotetext{
Pendahuluan

Potensi terjadinya celaka bisa dialami oleh semua pekerja, untuk pekerja fisik (menggunakan tenaga) baik di lingkungan formal maupun tidak formal.Pekerja fisik yang bekerja di lingkungan tidak formal seperti pekerja pemecah batu memiliki potensi yang besar untuk memperoleh celaka, hal ini disebabkan karena aktivitas

1) Email : Mimmanfatiha@gmail.com

2) Email : Djamaluddinramlan@gmail.com
}

dilakukan dengan peralatan seadanya, tanpa dilengkapi dengan alat pelindung diri dengan tuntutan produksi maksimal.

Adapun bentuk kecelakaan yang dialami oleh pekerja fisik seperti pemecah batu antara lain : luka pada mata, muka, badan, tangan, dan kaki akibat terkena serpihan batu, kondisi seperti diatas dialami oleh para 
pemecah batu di Desa Paningkaban, hal ini disebabkan karena pekerja beraktivitas tanpa alat pelindung diri berupa sarung tangan, kacamata, baju kerja lengan panjang.

Dari hasil wawancara peneliti dengan pekerja diketahui bahwa aktivitas pekerja pemecah batu dilakukan dengan cara batu dijepit kemudian dipukul dengan palu, hasil pengamatan diketahui ada serpihan dari pecahan batu yang mengenai anggota tubuh (tangan, kaki, badan, muka serta mata) hal ini bisa berlangsung berulang dan berpotensi mengakibatkan luka pada anggota tubuh yang terkena serpihan, ini terjadi karena palu pemecah batu tidak dilengkapi dengan tameng sebagai alat untuk mencegah sepihan batu mengenai anggota tubuh pekerja.

\section{Bahan dan Metode}

Penelitian ini dilaksanakan Penambangan Emas di Desa Paningkaban RT 04 RW 02 Kecamatan Gumelar Kabupaten Banyumas Propinsi Jawa Tengah.

Populasi dalam penelitian ini adalah Semua pekerja pemecah batu yang ada di bawah koordinasi Bapak Bambang dengan jumlah pekerja 14 orang.

Cara pengumpulan data yaitu berupa :

a. Wawancara

Pengumpulan data dengan melakukan serangkaian tanya jawab dengan Pemilik/Penanggung jawab industri pengolahan emas dan para pekerja pemecah batu tentang gambaran umum industri pengolahan emas serta proses pemecahan batu oleh peneliti dengan menggunakan kuesioner.

b. Pengamatan

Pengumpulan data secara langsung dengan mengamati proses pemecahan batu sebelum dan sesudah penambahan tameng palu menggunakan checklist.

c. Pengukuran

Pengumpulan data dengan cara mengukur jarak palu, lama kerja pemecah batu dan ukuran pemecah batu menggunakan checklist.

d. Penghitungan

Pengumpulan data dengan cara menghitung tingkat risiko kecelakaan kerja sebelum dan sesudah penambahan tameng palu menggunakan lembar tingkat risiko kecelakaan kerja.

Analisis data dilakukan Analisis data yang digunakan dalam penelitian ini meliputi :

a. Univariat

Data hasil penelitian ditabulasi untuk seterusnya menghitung nilai means, untuk memperoleh gabungan penambahan tameng palu terhadap pengurangan risiko kecelakaan pekerja di Penambangan Emas Desa Paningkaban.

b. Bivariat
Dari hasil penelitian ditabulasi yang selanjutnya dianalisis dengan menggunakan uji statistik Wilcoxon.

\section{Hasil dan Pembahasan}

Penambahan tameng palu dilakukan dengan cara menambahkan tameng berupa ban dalam bekas mobil yang di potong dengan pola lingkaran berdiameter 10 cm, kemudian tameng di letakkan pada kepala palu. Peneliti melakukan pengamatan sebelum dan sesudah penambahan tameng pada palu yang dilakukan selama 6 hari kerja.

1. Karakteristik Pekerja

Berdasarkan karakteristik pekerja yang dijadikan sebagai responden dapat di kelompokan sebagai berikut :

a. Umur Pekerja

Distribusi responden pemecah batu menurut kelompok umur di penambangan emas tahun 2016 sebagai berikut :

Tabel 4.1 : Distribusi responden pemecah batu menurut kelompok umur di penambangan emas tahun 2016

\begin{tabular}{|c|c|c|c|}
\hline No. & Kelompok Umur & $\begin{array}{l}\text { Jumlah } \\
\text { (orang) }\end{array}$ & $(\%)$ \\
\hline 1 & $21-30$ & 3 & 21.43 \\
\hline 2 & $31-40$ & 4 & 28.57 \\
\hline 3 & $41-50$ & 5 & 35.71 \\
\hline 4 & $51-60$ & 2 & 14.29 \\
\hline \multicolumn{2}{|r|}{ Total } & 14 & 100 \\
\hline
\end{tabular}

pekerjaterbanyak : 41 - 50 tahun karena pekerja bekerja lebih awal dan sebagai tumpuan keluarga.

b. Jarak Palu

Distribusi responden pemecah batu menurut jarak palu di penambangan emas tahun 2016 sebagai berikut :

Tabel 4.2 : Distribusi responden pemecah batu menurut jarak palu di penambangan emas tahun 2016

\begin{tabular}{|c|c|c|c|}
\hline No. & Jarak Palu & $\begin{array}{l}\text { Jumlah } \\
\text { (orang) }\end{array}$ & $(\%)$ \\
\hline 1 & $21-30 \mathrm{~cm}$ & 9 & 64.29 \\
\hline 2 & $31-40 \mathrm{~cm}$ & 5 & 35.71 \\
\hline \multicolumn{2}{|r|}{ Total } & 14 & 100 \\
\hline \multicolumn{4}{|c|}{$\begin{array}{l}\text { Berdasarkan tabel } 4.2 \text { diketahui jarak palu } \\
\text { terbanyak yang digunakan pekerja : } 21-30 \mathrm{~cm} \\
\text { karena pada jarak tersebut pekerja merasa nyaman } \\
\text { dan jumlah pukulan akan lebih banyak. } \\
\text { Waktu Kerja }\end{array}$} \\
\hline
\end{tabular}


Distribusi responden pemecah batu menurut waktu kerja di penambangan emas tahun 2016 sebagai berikut :

Tabel 4.3 : Distribusi responden pemecah batu menurut waktu kerja di penambangan emas tahun 2016.

\begin{tabular}{cccc}
\hline No. & Waktu Kerja & $\begin{array}{c}\text { Jumlah } \\
\text { (orang) }\end{array}$ & (\%) \\
\hline 1 & $1-2$ jam & 8 & 57.14 \\
2 & $3-4$ jam & 6 & 42.86 \\
\hline & Total & 14 & 100 \\
\hline
\end{tabular}

Berdasarkan tabel 4.3 diketahui bahwa waktu kerja terbanyak : 1 - 2 jam karena pekerja sudah mulai mengalami lelah.

d. Jenis Batu

Secara keseluruhan pekerja memecah batu jenis batu keras yang berasal dari Sungai Tajur yang bernama batu batu pasir / batu lanau.

e. Ukuran Pecahan Batu

Para pekerja pemecah batu memecah batu dari ukuran awal sebesar batu kerikil hingga menjadi serbuk ( tepung ) guna mempermudah proses pengolahan menggunakan mesin mixer.

2. Hasil Penelitian Tingkat Risiko Kecelakaan Kerja Sebelum dan Sesudah Penambahan Tameng pada Palu di Penambangan Emas Tahun 2016.

Table 4.4 : Hasil Penelitian Tingkat Risiko Kecelakaan Kerja Sebelum dan Sesudah Penambahan Tameng pada Palu di Penambangan Emas Tahun 2016.

$$
\text { No. Tingkat Risiko Jumlah Orang }
$$

\begin{tabular}{cccc}
\cline { 3 - 4 } & & Sebelum & Sesudah \\
\hline 1 & Tinggi & 2 & 0 \\
2 & Sedang & 12 & 0 \\
3 & Rendah & 0 & 14 \\
\hline & Total & 14 & 14 \\
\hline
\end{tabular}

Berdasarkan tabel 4.4 dikatakan bahwa tingkat kecelakaan pekerja sebelum menggunakan tameng palu berada pada tingkat risiko sedang dan tinggi hasil tersebut dilihat dari perkalian antara kemungkinan dan keparahan yang dialami para pekerja, untuk 2 orang yang masuk dalam kategori tinggi karena kedua pekerja memilih menggunaka palu dengan ukuran besar sehingga dalam proses pemecahan batu percikan batu mengenai anggota tubuh terutama bagian muka memiliki kemungkinan "Sering” terjadi dan membuat keparahan dalam level "Kecil” sehingga jika dikalikan antara keduanya dimana kemungkinan sering memiliki nilah 5 dan keparahan kecil dengan nilai 2 maka hasil perkaliannya adalah 10 dimana dari matriks tingkat risiko kecelakaan kerja masuk kedalam kategori tingkat risiko "Tinggi” ditambah dengan waktu kerja yang cukup lama yaitu 3-4 jam , untuk 12 orang lainnya masuk dalam kategori tingkat risiko "Sedang” karena mereka memilih palu dengan ukuran sedang sehingga perpercikan batu yang terjali lebih jarang dibandingakan dengan menggunakan palu ukuran besar kemungkinannya pun menjadi mungkin dan kadang - kadang serta keparahan yang kecil mengakibatkan tingkat risiko yang dialami oleh 12 orang lainnya menjadi “Sedang”, kemudian setelah menggunakan tameng palu tingkat risiko kecelakaan kerja menjadi ringan karena walaupun mereka memilih jenis palu yang berbeda setelah penambahan percikan ke arah muka tidak lagi terjadi yang artinya terjadi pengurangan tingkat risiko kecelakaan kerja.

\section{Kesimpulan}

Jumlah tingkat risiko kecelakaan kerja sebelum penambahan tameng tingkat risiko kecelakaan tinggi sebanyak 2 orang pekerja, dan tingkat risiko kecelakaan sedang 12 orang pekerja.

Jumlah tingkat risiko kecelakaan kerja setelah penambahan tameng palu seluruh responden ( 14 orang ) mengalami penurunan tingkat risiko menjadi "Ringan".

Berdasarkan hasil analisis data dengan uji statistik Wilcoxon diperoleh nilai $\mathrm{Th}>\operatorname{Tt}(23>21)$, artinya ada pengaruh penambahan tameng palu terhadap pengurangan risiko kecelakaan kerja.

\section{Ucapan Terimakasih}

Terima kasih disampaikan kepada Penambangan Emas dibawah koordinasi Bapak Bambang Priyono, Jurusan Kesehatan Lingkungan, dosen pembimbing Karya Tulis Ilmiah Politeknik Kesehatan Kemenkes Semarang serta pihak-pihak yang terkait sehingga penelitian ini dapat terlaksanakan.

\section{DAFTAR PUSTAKA}

Ade Nurjaman Hs, 1989, Pencegahan Kecelakaan, Jakarta : PT Pustaka Binaman Pressindo.

Alfian Alhaq, 2015, Perkakas Tangan dan Fungsinya. http://engineerstudy23.blogspot.co.id/2015/09/ perkakas-tangan-dan fungsinya.html. Akses Desember 2015.

Aris Santjaka, 2011, Statistik Untuk Penelitian Kesehatan, Deskriptif, Inferensial, Parametrik dan Non Parametrik, Yogyakarta: Nuha Medika.

Budiono, Sugeng, Jusuf, RMS, Pusparini, Andrianan, 2005, Bunga Rampai, Hiperkes \& KK, Higiene Perusahaan, Ergonomi, Kesehatan 
Kerja, Keselamatan Kerja, Semarang: Badan Penerbit Universitas Diponegoro.

Djamaluddin Ramlan, 2006, Dasar-dasar Kesehatan Kerja II, Purwokerto: Jurusan Kesehatan Lingkungan Purwokerto, Politeknik Kesehatan DEPKES Semarang.

Djamaluddin Ramlan, Maisye Marlyn Kuhu, 2014, Petunjuk Praktis, Penulisan Penelitian Eksplanatif, Purwokerto: UPT. Percetakan dan Penerbitan Universitas Jendral Soedirman Kampus UNSOED Grendeng.

Halim DN, 2013, Macam macam palu dan fungsinya. http://automotivea17.blogspot.co.id/2013/08/m acam-macam-palu-dan- fungsinya.html. Akses Desember 2015.

Intan Anggraini, 2015, Pengaruh Pemakaian Masker "Intan" Terhadap Kenyamanan Pekerja Penggilingan Padi Di Desa Kuripan Kecamatan Kesugihan Kabupaten Cilacap Tahun 2015, KTI, Purwokerto: Kementrian Kesehata RI Politeknik Kesehatan Kemenkes Semarang Jurusan Kesehatan Lingkungan Purwokerto.

Johari, 2012, Cara Tambang Emas Tradisional.https://joharidb.wordpress.com/201 2/11/27/cara-tambang- emas-tradisional/.

Akses Desember 2015.

Mukono, Penta B. Wasono, 2002, Pertolongan Pertama pada Kecelakaan Kerja, Surabaya: Airlangga University Press.

Soehatman Ramli, 2010, Pedoman Praktis Manajemen Risiko dalam Perspektif OHS Risk Managemen, Jakarta: PT. Dian Rakyat.

Sritomo Wignjosoebroto, 2008, Ergonomi, Studi Gerak dan Waktu, Tenik Analisis Untuk Peningkatan Produktiitas Kerja, Surabaya: Prima Printing.

Suma'mur P.K, 2009, Higiene Perusahaan Dan Kesehatan Kerja (HIPERKES), Jakarta: PT Inti Idayu Press.

Umi Ambarwati, 2013, Pengaruh pemakaian Rancangan Rangka Jilbab (Ciput) ErgonomisTerhadapKenyamanan

Penggunannya Pada Mahasiswi Jurusan Kesehatan Lingkungan Tahun 2013, KTI, Purwokerto : Kementrian Kesehatan RI Politeknik Kesehatan Kemenkes Semarang
Purwokerto.

Jurusan Kesehatan Lingkungan

Wikipedia,

2014.

Palu

(alat).https://id.wikipedia.org/wiki/Palu_\%28al at\%29. Akses Desember 2015.

Wowo Sunaryo K, 2014, Ergonomi dan K3, Kesehatan Keselamatan Kerja, Bandung: PT Remaja Rosdakaya.

\section{$\mathrm{T}$}

